\title{
HUMAN SECURITY DALAM NEGARA DEMOKRASI: PERSPEKTIF MEDIA STUDIES
}

\author{
Kazan Gunawan \\ Lembaga Ketahanan Nasional Republik Indonesia (Lemhannas RI) \\ Irwan Abdullah \\ Fakultas Ilmu Budaya Universitas Gadjah Mada \\ Heru Nugroho \\ Fakultas Ilmu Sosial dan Ilmu Politik Universitas Gadjah Mada
}

\begin{abstract}
The aim of this article is to explain the relation between human security and media studies when looking at the problem of security in Indonesia, a country experiencing a process of democratization. In media studies, the problem of human security often only emphasizes discourse and event analysis, without relating it with the human security problem. Connecting human security and media is very important because media has a very important role in constructing the public and State's opinion. This article analyses news, as reported in the media, then gives context about the State and problems related to human security. It is concluded that media is highly influential in studying human security because of its numerous economic, political and cultural interests.
\end{abstract}

Keywords: Human Security, Media, Democratic State

\begin{abstract}
ABSTRAK
Tulisan ini bertujuan untuk menjelaskan keterkaitan antara keamanan manusia atau human security dengan kajian media atau media studies dalam melihat persoalan keamanan di Indonesia sebagai negara yang sedang menuju proses demokratisasi. Dalam kajian media, masalah-masalah keamanan manusia seringkali diberitakan tetapi lebih menekankan pada aspek analisis wacana atas peristiwa tanpa menghubungkannya dengan persoalan keamanan manusia. Menghubungkan human security dengan media menjadi penting karena media berperan besar sebagai pembentuk opini masyarakat dan negara. Kajian ini dilakukan dengan cara menganalisis berita di media, memberi konteks tentang negara dan masalahmasalah yang menjadi pokok dalam keamanan manusia. Simpulan yang ditarik antara lain adalah bahwa media sangat berpengaruh dalam kajian keamanan manusia karena memiliki pelbagai kepentingan, ekonomi, politik, dan kebudayaan.
\end{abstract}

Kata Kunci: Keamanan Manusia, Media, Negara Demokrasi 


\section{PENGANTAR}

Dalam sepuluh tahun terakhir situasi Indonesia terus mengalami dinamika politik yang luar biasa. Setelah konstelasi politik nasional mengalami perubahan secara cukup signifikan, dari sistem pemerintahan otoritarian menjadi pemerintahan yang demokratis, kehidupan politik berlangsung secara dinamis. Artikulasi politik masyarakat terus menguat yang diekspresikan dalam bentuk unjuk rasa menuntut berbagai kepentingan politik, ekonomi, sosial, dan budaya.Apa saja yang mengusik kepentingannya, warga masyarakat begitu cepat bereaksi dan kemudian melakukan demonstrasi turun ke jalan, yang tidak jarang menjurus pada tindakan anarkis. Pemahaman tentang konsep keamanan nasional juga mengalami perubahan mengikuti konteks dan dinamika perkembangan masyarakat. Secara konvensional, pemahaman terhadap konsep keamanan nasional cenderung dikaitkan dengan situasi peperangan, kontes militer, atau parade kekuatan bersenjata untuk menghadapi suatu pertempuran terbuka. Ancaman dinilai bersifat pendudukan wilayah serta adanya ekspansi asing atau perang teritorial. Pemahaman tersebut menjadi identik perang dengan tendensi pengerahan seluruh kekuatan rakyat yang dipersenjatai untuk menyambut sebuah peperangan akbar (Nef, 1999; Thomas, 2000).

Dalam pemahaman kontemporer, konsep keamanan nasional secara konvensional tersebut mulai terasa kurang relevansinya, bukan saja karena peperangan teritorial secara terbuka menguras biaya dan korban yang banyak, tetapi juga memeras energi moral dan psikologis warga negara. Pemahaman tersebut juga tidak sesuai lagi dengan kondisi faktual perkembangan peperangan generasi keempat (4thGW) yang mengisyaratkan format keamanan nasional tidak lagi bersifat linier (battlefield) tetapi bersifat spasial yang besar (battlespace), yakni penggunaan ruang-ruang yang ada dalam konteks sosial, politik, dan kultural dalam kehidupan kemasyarakatan. Media, misalnya, dapat ditempatkan dalam ruang ini. Penyiaran berita tentang persoalan keamanan nasional di media, seperti konflik etnik, klaim suatu wilayah oleh negara asing serta terorisme merupakan ruang (battlespace) yang dimaksud. Dalam ruang media inilah keamanan nasional menjadi ajang kontestasi dari sisi politik, sosial, dan kultural. Pemaknaan baru terkait persoalan keamanan nasional pada masa kini muncul menggantikan konsepsi dan pemahaman tradisional-konvensional tentang kemanan nasional. Keamanan nasional tidak dapat dipisahkan dari perkembangan nilai dan tatanan global yang dapat melahirkan krisis dan ancaman (Thomas, 2000: 8).

Pada masa kini, persoalan keamanan nasional memiliki pula dinamisme yang kompleks dengan merujuk pada definisi kontemporer. Persoalan terorisme misalnya, yang menjadi masalah keamanan nasional masa kini di Indonesia dan dunia dapat menjadi contoh bagaimana persoalan ini melibatkan pula persoalan discourse yang luas. Penangkapan teroris yang disiarkan lewat media membuktikan wacana baru battlespace selain battlefiled antara yang berwenang dengan para teroris. Masalah keamanan nasional tidak hanya menjadi persoalan negara tetapi seluruh masyarakat dengan peran media menjadi agen-agen baru yang terlibat dalam membangun kembali konsep keamanan nasional ini. Media menjadi kekuatan baru yang turut mengkonstruksi mindset khalayak terhadap konsep keamanan nasional dan bahkan mampu membentuk bangunan dan menggerakkan kekuatan sosial.

Kendati media dapat diletakkan sebagai suatu institusi ekonomi, tetapi diskursus seputar media tidak sesederhana membincangkan institusi ekonomi yang lazimnya bergerak dalam sektor produksi, komodifikasi, distribusi dan konsumsi. Media memiliki kekuatan menyebarkan, mempromosikan, mempengaruhi, mengubah bahkan membentuk berbagai konstruksi sosial (Fairclough, 1995). Kekuatan inilah yang acap menjadi sorotan dan topik dalam studi media. Persoalan keamanan nasional dengan 
demikian mengalami pendefinisian kembali oleh media. Ada definisi-definisi dan realita-realita baru yang diketengahkan oleh media ketika memotret persoalan keamanan nasional. Keamanan nasional menjadi lebih luas dan meliputi aspek-aspek yang lebih luas pula menyangkut persoalan yang beragam pula, mulai dari human trafficking, terorisme, dan persoalan human security secara luas.

Pada konteks keamanan nasional yang sangat spesifik dalam penelitian ini, media juga dapat diletakkan sebagai pilar penjaga keamanan dan pertahanan nasional. Sebagaimana dalam hal menjaga keamanan dari bencana alam misalnya, negara juga memiliki tanggungjawab konstitusional untuk memberikan jaminan rasa aman dari bahaya bencana alam. Pada pertengahan bulan Oktober hingga pertengahan November 2010 terjadi peristiwa bencana alam yang ditimbulkan oleh erupsi Gunung Merapi yang terletak di perbatasan Jawa Tengah dan Yogyakarta. Pada tanggal 26 Oktober 2010, terjadi erupsi eksplosif Gunung Merapi dengan mengeluarkan awan panas dan memiliki jarak luncur hingga $4 \mathrm{~km}$. Kemudian erupsi eksplosif yang lebih besar terjadi lagi pada tanggal 4 November 2010 dengan mengeluarkan awan panas yang jarak luncurnya mencapai $7 \mathrm{~km}$.

Atas pertimbangan tersebut, maka representasi dan konstruksi media televisi atas realitas di seputar bencana erupsi Gunung Merapi menjadi menarik diangkat menjadi topik studi ini. Nilai urgensinya menjadi semakin tinggi ketika media pada era liberalisasi media seperti sekarang ini mengalami perubahan secara signifikan dalam perilakunya. Melalui analisis wacana kritis, menarik diketahui bagaimana relasi antara media dan negara pada era liberalisasi media sekarang ini. Oleh karena itu, tulisan ini berpotensi untuk menemukan teori baru dalam kasanah studi budaya dan media.

Selama tahun 1980-an, latar belakang teoretis dalam studi media berubah secara signifikan. Sejumlah pendekatan baru un- tuk mempelajari media bermunculan, dan pendekatan-pendekatan baru inilah yang kini menjadi varian utama studi media (Sardar, 2008: 52). Beberapa pendekatan baru itu antara lain studi institusional, struktural, dan poststrukturalisme. Pendekatan institusional penekanannya terletak pada faktorfaktor yang mengatur hubungan di dalam organisasi dan menjaga keseluruhan struktur. Isi dan keluaran media dijelaskan sebagai hasil dari interaksi di antara berbagai anggota organisasi media. Sementara itu gagasan struktural tentang media didasarkan pada semiotika dan dekonstruksi, yaitu suatu model analisis filosofis yang berhubungan dengan tulisan Jacques Derrida. Gagasan mendasar dalam studi ini adalah pada sistem dan proses-proses signifikasi (penandaan) dan representasi. Studi media kaum strukturalis juga dihubungkan dengan reformulasi ideologi dari filosof Marxis dari Perancis, Louis Althusser. Sejak dekade 1970-an, kombinasi Marxisme Althusserian dengan semiotika memberikan daya dorong utama bagi penelitian berkelanjutan terhadap teks-teks media. Sedangkan pendekatan poststrukturalisme lebih berhubungan dengan teori-teori psikoanalisis dan peran dari penikmat dalam memproduksi dan meregulasi makna. Oleh karena itu, hubungan teks-teks dengan subyek diteorisasikan. Subyek di sini bukanlah subyek Althusser atau Marxisme tradisional, tetapi merupakan subyek yang kontradiksionaris dan tidak berpusat, berpindah-pindah di sepanjang jangkauan wacana di mana subyek berpartisipasi (Sardar, 2008: 58).

Kedua, perspektif yang dikemukakan oleh Lazarsfeld yang membedakan antara perspektif kritis dan orientasi administratif. Asumsi yang dikembangkan adalah, menutut teori kritis memfokuskan dan menggarisbawahi problem-problem dan kesalahan praktek media dan hubungan mereka dengan isu-isu sosial yang dipandu oleh nilainilai tertentu. Teori-teori terapan bertujuan memanfaatkan dan memahami proses komunikasi untuk menyelesaikan problem praktis dengan menggunakan komunikasi 
massa secara efektif (Windahl dan Signitzer, 1991, dalam McQuail's, 2005: 12).

Ketiga, berusaha membedakan dengan istilah pendekatan "media sentries" dan "sosio-sentris". Asumsi yang dikembangkan adalah, menurut teori media sentris melihat media sebagai penggerak utama dalam perubahan sosial, mendorong kemajuan dengan perkembangan teknologi komunikasi yang tak terbendung. Sedangkan teori sosio-sentris asumsi utamanya bahwa media sebagai refleksi kekuatan ekonomi dan politik. Dengan demikian teori media menjadi lebih merupakan bagian kecil dari teori sosial yang lebih luas (Golding dan Murdock, 1978 dalam McQuil's, 2005:13).

Sedangkan ditinjau dari dimensi dan tipe-tipe teori media, dibedakan menjadi empat pendekatan utama yang dapat diidentifikasi menurut dua dimensi: mediasentris versus sosio-sentris; kulturalis versus materialis. (1) Perspektif kulturalis-media yang memberikan perhatian utama terhadap isi media dan bentuk serta penerimaan subyektif pesan media dipengaruhi oleh lingkungan personal terdekat; (2) Perspektif media-materialis yang menekankan aspek organisasional, finansial, dan teknologi media; (3) Perspektif sosial-kulturalis yang menekankan pengaruh faktor-faktor sosial pada produksi media dan penerimaan serta fungsi-fungsi media dalam kehidupan sosial; dan (4) Perspektif sosialmaterialis yang melihat media dan isi utamanya sebagai refleksi dari kekuatan politik dan ekonomi, sertra refleksi kondisi (McQuill's, 2005: 14).

Stuart Hall misalnya, telah menjelaskan proses itu melalui teori Encoding and Decoding in the Televisual Discourse. Dalam model komunikasi televisual dari Hall, sirkulasi makna dalam wacana televisual melewati tiga momen yaitu tahap encoding, wacana yang bermakna, dan decoding. Dalam momen encoding realitas mentah yang terdapat di masyarakat telah mengalami proses seleksi oleh praktisi media yang dipengaruhi oleh kerangka pengetahuan, hubungan produksi, dan sarana teknis. Realitas mentah yang telah berproses pada tahap encoding itu kemudian dilempar ke publik dalam bentuk wacana yang bermakna, yang ini merupakan momen kedua. Kemudian wacana yang bermakna itu sampai ke khalayak masuk dalam momen decoding. Di sini programprogram televisi yang sampai pada khalyak kembali mengalami proses pemaknaan berdasarkan kerangka pengetahuan, hubungan produksi, dan sarana teknis dari para pemirsa (Hall, 1973).

Sementara itu Shoemaker dan Reese (1991) berasumsi bahwa politik representasi media memberikan penegasan bahwa dalam memproduksi realitas, pihak media sudah menciptakan konstruksi serta sudut pandang tertentu terhadap realitas sosial yang dihadapi. Semua ini terjadi dalam tatanan bersifat hierarkis serta berlangsung simultan melalui berbagai mekanisme mulai dari sikap, kepentingan, dan latar belakang keyakinan praktisi media hingga pemilik dan sistem pemerintahan di mana media itu berada.

Beberapa asumsi politik representasi media adalah: bahwa apa pun yang ditampilkan media bukanlah cermin realitas sosial; persoalan utamanya justru terletak pada bagaimana media menyajikan kembali realitas sosial yang dilaporkannya; dan representasi yang dijalankan media berarti menghadirkan lagi berbagai fakta dan apa yang dianggap sebagai realitas sosial. Oleh karena itu dalam politik representasi media senantiasa mempertanyakan: bagaimana representasi realitas sosial dalam media dapat dibandingkan dengan realitas sosial yang "nyata"?; representasi merupakan hasil seleksi yang bersifat sangat beragam. Bergantung kepentingan yang ada di baliknya, sehingga pasti ada realitas yang disembunyikan; media tidak mungkin mampu berfungsi sebagai cermin realitas, karena keterbatasan ruang dan waktu yang tersedia; klaim "nyata" dan "benar" itu menurut konstruksi siapa? Pandangan konstruksionis meyakini bahwa tidak ada representasi yang nyata dan benar, tergantung konstruksi siapa. 


\section{PEMBAHASAN}

\section{Media, Masyarakat, dan Ideologi}

Hubungan antara masyarakat, kebudayaan dan media massa sangat erat, karena keberadaan ketiganya tidak bisa dipisahkan satu sama lain. Karena itu banyak teoretikus dan perspektif teori yang berusaha menjelaskan hubungan media massa dan masyarakat, serta budaya. Pada kenyataannya banyak teori media berhubungan dengan baik kebudayaan maupun masyarakat, dan juga berusaha menjelaskan keduanya. Para teoritisi dan perspektif teori utama yang terus berkembang untuk menjelaskan caracara media bekerja dan menguraikan produksi budaya yang tipikal. Penjelasan teoretik tentang hubungan antara kebudayaan dan masyarakat dalam kaitannya pula dengan media massa, berkisar pada asumsi struktur sosial mempengaruhi kultur, dan sebaliknya kultur mempengaruhi struktur sosial.

Dalam upaya menjelaskan hubungan antara media, masyarakat, dan budaya, Rosengren (1981b) berusaha membuat tipologi sederhana dalam tabulasi silang yang menunjukkan proposisi berlawanan: "struktur sosial mempengaruhi kebudayaan"; dan sebaliknya, "kebudayaan mempengaruhi struktur sosial", sebagaimana dapat dilihat dalam diagram berikut.

Struktur sosial mempengaruhi struktur

\begin{tabular}{ll}
\multicolumn{1}{c}{ Yes } & \multicolumn{1}{c}{ No } \\
\hline $\begin{array}{l}\text { Interdependesi } \\
\text { (pengaruh dua arah) }\end{array}$ & $\begin{array}{l}\text { Idealisme (pengaruh } \\
\text { media kuat) }\end{array}$ \\
\hline $\begin{array}{l}\text { Materialisme } \\
\text { (Media tergantung }\end{array}$ & $\begin{array}{l}\text { Otonomi } \\
\text { (tidak ada hubungan } \\
\text { sebab akibat }\end{array}$ \\
\hline
\end{tabular}

Terdapat dua model kekuatan media, yang keduanya saling bertentangan, yaitu model media dominan dan media pluralis. Model media dominan melihat media sebagai yang menggunakan kekuatan atas nama lembaga-lembaga kuat. Organisasi media, dalam hal ini dimiliki dan dikontrol oleh sekelompok kecil yang memiliki kepen- tingan. Model ini senantiasa mengkritik pada sistem kapitalis yang menggunakan media sebagai instrument imperalisme budaya dan hanya sebagai alat propaganda oleh kelompok dominan. Sementara itu model pluralis berasumsi bahwa media mempuyai ruang untuk tumbuh, sehingga media menjadi banyak dan masing-masing independen.

Menurut Lull, perkembangan teori kebudayaan dan komunikasi kritis dewasa ini telah mengarahkan perhatiannya pada ideologi, kesadaran, dan hegemoni. Ketiga konsep tersebut saling berhubungan dan saling berkait satu sama lain, dengan masing-masing mempunyai peran dan penekanannya sendiri-sendiri yang unik. Seluruh konsep-konsep tersebut akan didiskusikan dalam buku ini. Untuk mengenalkan konsep-konsep itu, kita dapat mengatakan bahwa ideologi adalah sebuah sistem ide yang diekspresikan dalam komunikasi; sedangkan kesadaran adalah pokok atau totalitas perilaku, pandangan-pandangan, kepekaankepekaan yang dimiliki oleh individu atau kelompok; dan hegemoni adalah suatu proses di mana ideologi dominan ditransmisikan, kesadaran dibentuk, dan kekuasaan sosial dijalankan.

Selain persoalan ideologi, hegemoni adalah kekuatan yang menunjukkan satu kelompok sosial tertentu mengontrol lainnya. Hal itu dapat merujuk pada saling ketergantungan asimetris dari hubungan politik, ekonomi, kebudayaan antarbangsa atau antarnegara (Straubhaar, 1991), atau perbedaan antar-kelas sosial dalam suatau negara. Hegemoni adalah dominasi dan subordinasi dalam arena relasi yang dikontrol oleh kekuasaan (Hall, 1985). Namun menurut Lull hegemoni lebih dari kekeuasaan sosial itu sendiri. Hegemoni adalah sebuah metode untuk untuk mencapai dan memelihara kekuasaan. Akan tetapi, dalam kenyataannya, ideologi dominan bukanlah kodekode yang menyatu. Media menunjukkan bahwa semua itu adalah bervariasi dan penuh kontradisi.

Selanjutnya, efek representasi ideologi mediasi teknologi tidak dapat diprediksi de- 
ngan mudah. Tak ada respons sosial yang seragam pada perspektif media yang diletakkan oleh media massa dan saluran informasi publik lainnya. Selama ideologi dominan ditanam secara hegemonik dan memberi kontribusi pada pembentukan kesadaran arus utama, kemanusiaan- sebagai individu, anggota khalayak, anggota keluarga, pekerja, mahasiswa, dan anggota kelompok sosial baik formal maupun non-formal menafsir danmenggunakan media (baik isi maupun bentuknya) sedikit banyak tentu saja tidak selalu sesuai dengan pesan penerima. Selanjutnya, ideologi bukan arus utama (kadang-kadang radikal) menyebar lewat media alternatif (media bawah tanah) dan juga membantu mengembangkan polapola sosial alternatif (kadang-kadang subversif). Oleh karena itu, ideologi, media, dan aktivitas sosial, semuanya meliputi wilayah kesesuaian dan kontestasi.

\section{Media dan Konstruksi atas Realitas}

Persoalan konstruksi media dalam memotretkan masalah keamanan nasional sangat penting ditinjau dari beberapa teori yang mendukung. Persoalan konstruksi dalam hal ini merujuk pada teori konstruksi sosial realitas. Konsepsi konstruksi realitas sosial dapat diacu pada pemikiran Peter L. Berger dan Thomas Luckmann dalam Social Construction of Reality, A Treatise in the Sociology of Knowledge (1966). Kerangka teori konstruksi realitas Berger dan Luckmann mengetengahkan terlebih dahulu pemisahan antara "kenyataan" dan "pengetahuan". "Kenyataan" merupakan kualitas fenomena yang memiliki keberadaan (being), tidak tergantung oleh kehendak manusia, bahkan tidak dapat ditiadakan atau diciptakan oleh angan-angan sekalipun.

Adapun "pengetahuan" merupakan kepastian bahwa fenomena sosial tersebut nyata (real) dan memiliki karakteristik dan kategori yang spesifik. Orang dapat berbeda memandang realitas karena mental dan pengetahuan sangat mempengaruhi yang bersifat riil. Namun demikian, hubungan antara yang riil dan pengetahuan sangat erat. Bila pengetahuan diproses secara terusmenerus, ia dapat menjadi suatu realitas. Baik realitas maupun pengetahuan, keduanya berangkat dari gejala sosial dalam kehidupan bermasyarakat yang terus-menerus berproses. Oleh karena itu, pemahaman terhadap gejala sosial ditemukan dalam pengalaman masyarakat. Terdapat kaitan yang erat antara realitas dan pengetahuan. Dalam kehidupan sosial, seperangkat pengetahuan yang diproses secara terus-menerus kemudian ditetapkan secara sosial sebagai suatu kenyataan.

Menurut Berger dan Luckmann, realitas sosial dikonstruksi melalui tiga mekanisme: Eksternalisasi, yaitu pencurahan diri baik fisik dan mental setiap individu dalam dinamika masyarakat yang mengitarinya. Objektivasi, yaitu proses interaksi dan sosialisasi makna subjektif setiap individu terhadap makna subyektif individu lainnya. Atau dengan kata lain, hasil dari proses eksternalisasi individu tersebut menghasilkan realitas obyektif. Lewat proses objektivasi tersebut masyarakat menjadi suatu realitas sui generis. Internalisasi, yaitu menampilkan realitas objektif yang tertanam dalam individu atau pelaku sosial tadi akan disebarkan atau disosialisasikan pada individu atau pelaku sosial lainnya. Dalam tahap ini, kembali realitas objektif akan mengalami pemaknaan dan persepsi dari individu atau pelaku sosial lainnya. Berbagai macam unsur dari dunia yang telah terobjektifkan akan ditangkap kembali sebagai gejala realitas di luar kesadaran individu.

Dalam perspektif ini, sebagian atau bahkan seluruh isi media dapat dikatakan merupakan hasil konstruksi. Akan tetapi, media juga memiliki kemampuan tertentu dalam menciptakan citra suatu realitas. Dari sinilah sebetulnya proses eksternalisasi dan internalisasi tersebut berlangsung. Isi media merupakan lokasi atau forum yang menampilkan berbagai peristiwa yang terjadi sehingga bagi masyarakat berfungsi untuk memperoleh gambaran atau citra realitas dan sekaligus nilai dan penilaian normatif terhadap realitas tersebut. Proses konstruk- 
si realitas oleh media pada prinsipnya merupakan upaya "menceritakan" (konseptualisasi) sebuah peristiwa. Karena pekerjaan media massa adalah "menceritakan" rangkaian peristiwa, maka seluruh isi media merupakan realitas yang telah mengalami proses konstruksi kembali. Pembuatan berita media massa pada dasarnya adalah penyusunan atau proses konstruksi kumpulan realitas-realitas sehingga menimbulkan wacana yang bermakna. Secara sederhana prosesi konstruksi media terhadap realitas tersebut digambarkan oleh Hamad (2003) sebagaimana berikut;
Menurut Pamela J. Shoemaker dan Stephen Reese (1996) pada dasarnya konstruksi berita oleh media merupakan sebuah kesatuan informasi verbal dan visual yang didistribusikan secara kuantitatif dan kualitatif di dalam media. Dalam hal ini, informasi yang disajikan oleh media dapat diukur secara kuantitatif dari unsur jumlah pemberitaannya. Sedangkan secara kualitatif dapat dilihat pada sebutan istilah atau pemakaian istilahnya atau berdasarkan persepsi dari khalayaknya (kualitatif). Namun demikian, kualitas suatu konstruksi dapat dilihat dari unsur objektivitas dan faktuali-

Realitas atau fakta dalam bentuk peristiwa, keadaan, orang dan benda

(1)

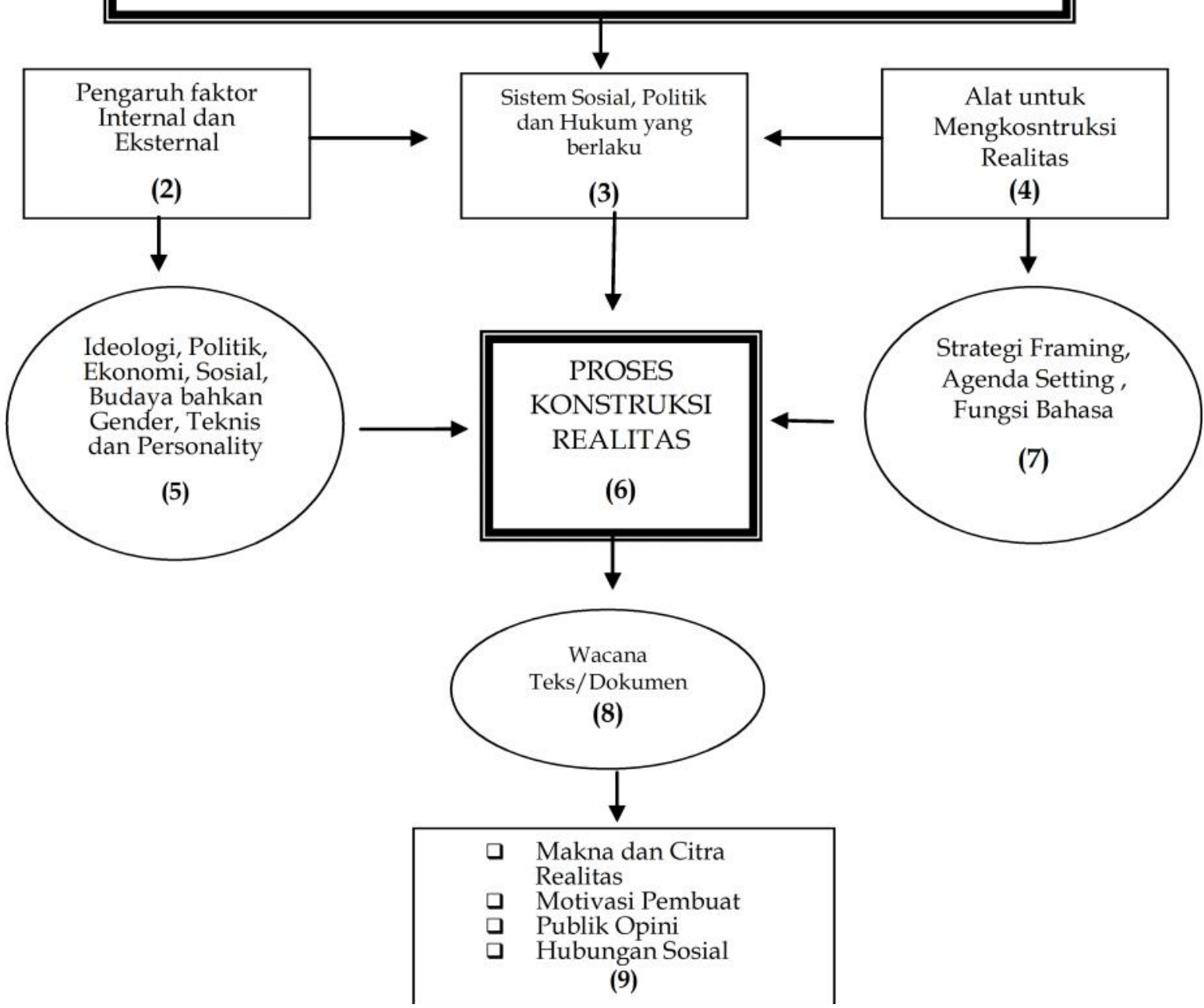

Gambar 1.

Prosesi konstruksi media terhadap realitas 
tas. Objektivitas dapat diukur dari media reality dan social reality. Sedangkan faktual, artinya berita memuat kebenaran berdasarkan fakta yang relevan dengan peristiwa. Oleh karena itu, kualitas suatu konstruksi ditentukan dan dipengaruhi oleh banyak faktor. Shoemeker dan Reese (1996) menyebutkan berbagai faktor yang secara hirarkis dapat mempengaruhi isi media.

Konstruksi atas realitas sebagaimana dikemukakan Berger dan Luckmann dalam konteks keamanan nasional berhubungan dengan media beserta dinamikannya. Realitas keamanan nasional secara formal seringkali dinyatakan secara tegas dalam sebuah paket undang-undang maupun dalam pengertian tersirat dengan menggunakan istilah lain seperti "keselamatan nasional". Namun demikian, dapat juga dipahami dan diterima secara sosial melalui mekanisme konvensi. Secara historis, konsep keamanan nasional merujuk pada negara-negara yang terbentuk negara-bangsa (nation-state). Sebagaimana lazimnya karakter negarabangsa, di sini juga berlaku asas common sense, kepentingan nasional berada di atas kepentingan golongan maupun individu. Penelusuran lebih jauh terhadap konsep keamanan nasional dapat diusut pada awal mula perang yang bersifat massal dalam arti mengerahkan seluruh komponen kekuatan nasional diperkenalkan oleh Napoleon ketika melakukan penguasaan Eropa.

Perang Napoleon dikenal dengan Levée en masse (perang semesta). Levée en masse versi perang Napoleon kemudian memberi inspirasi kepada Adam Robert untuk memilah negara bangsa (nation state) menjadi dua kelompok yaitu negara kesejahteraan (welfare state) dan Negara Bersenjata (armed state). Secara garis besar negara kesejahteraan (welfare state) menunjuk pada sebuah model ideal pembangunan yang difokuskan pada peningkatan kesejahteraan melalui pemberian peran yang lebih penting kepada negara dalam memberikan pelayanan sosial secara universal dan komprehensif kepada warganya. Negara kesejahteraan (welfare state) mengutamakan kesejahteraan bagi rakyat/bangsanya. Perubahan orientasi ini ditegaskan oleh UNDP:

"For most people today, a feeling of insecurity arises more from worries about daily life than from the dread of a cataclysmic world event. Job security, income security, health security, environmental security, security from crime, these are the emerging concerns of human security all over the world" (Thomas, 2000: 7).

Konteks ini telah melahirkan sikap penolakan perang secara meluas. Sedangkan negara bersenjata adalah negara yang mempersenjatai rakyatnya karena mereka dibayangi ketakutan akan invasi bangsa lain. Dari sinilah lahir konsep perang semesta dan konsep tentara rakyat. Perkembangan selanjutnya ada yang menyebutnya sebagai perang total (total war) konotasi yang lebih halus menyebutnya pertahanan total (total defence). Negara komunis menyebutnya dengan perang rakyat (people war) konotasi yang lebih halus menyebutnya pertahanan rakyat (people defence). Atas dasar gabungan berbagai teori-doktrin tentang perang itulah maka para pejuang kemerdekaan RI kemudian menyusun doktrin sendiri (doksen) yaitu doktrin pertahanan keamanan rakyat semesta (doktrin Hankamrata) dan dituangkan dalam suatu sistem yaitu Sistem Pertahanan Keamanan Rakyat Semesta (Sishankamrata) (Purwanegara, 2009).

Konsep historis Hankamrata mengandaikan sistem pertahanan yang melibatsertakan rakyat secara menyeluruh dan menempatkan negara bukan sebagai satu-satunya pihak yang bertanggung jawab dalam penyelenggaraan keamanan nasional. Oleh karena itu, negara bukanlah satu-satunya pihak yang dijadikan referensi bagi keamanan nasional dan kelangsungan suatu negara. Pengertian implisit yang terkandung di dalamnya adalah, walaupun pada prakteknya ada klasifikasi komponen kekuatan keamanan nasional seperti komponen dasar Rakyat Terlatih (Ratih), Komponen Utama TNI dan Komponen Khusus Perlindungan Masyarakat, Melihat frekuensi konflik yang terjadi semasa pemerintahan Megawati yang dilakukan oleh rakyat, mengindikasikan bah- 
wa Ia kurang berhasil dalam membangun demokrasi secara substansial. Lemahnya kemampuan mengelola konflik di tubuh partainya sendiri, sehingga seringkali menimbulkan konflik di kalangan massa juga menjadi indikator ketidakberhasilan dalam meningkatkan kualitas demokrasi. Namun secara substantif roh Hankamrata tidak mengenal dikotomi kekuatan pertahanan keamanan nasional. Hal ini karena pada prinsipnya seluruh warga negara bertanggung jawab dan siap berjuang/berkorban demi menjaga keamanan nasional. Implikasi dari pemahaman ini berakibat pada meluasnya makna keamanan nasional. Keamanan nasional bukan lagi persoalan peperangan atau pertahanan segenap komponen negara baik kombatan maupun nonkombatan terhadap ancaman agresi atau serangan militer asing tetapi menyangkut keamanan dalam segala sektor yang mengancam kelangsungan kehidupan manusia. Dalam terminologi kontemporer, perspektif ini dikenal dengan human security (UNDP, 1994; Human Security Centre, 2005).

Menurut Human Security Report 1994 (UNDP, 1994) setidaknya terdapat empat karakteristik, yang pada dasarnya merupakan asumsi pembentuk human security, yakni: (1) universalitas, bahwa human security bersifat universal, bersama atau relevan untuk semua orang di manapun; (2) human security memiliki karakter interdependen dalam arti bahwa tidak mungkin membatasi sebuah ancaman dalam batas-batas spasial atau temporal tertentu; (3) ancaman terhadap human security lebih optimal dilakukan dengan pencegahan daripada intervensi atau penanganan; dan (4) human security berorientasi pada manusia (people-centered), yakni bagaimana orang hidup dalam masyarakat, seberapa bebas mereka menentukan pilihan ataupun apakah mereka punya akses terhadap berbagai peluang yang ada.

Jadi jelas, konsepsi keamanan nasional dalam arti human security harus memberi tekanan yang lebih kuat pada keamanan manusia atau masyarakat daripada ke- amanan atau integritas negara. Sejalan dengan konsepsi ini Iorge Nef (1999) mengatakan bahwa:

"Most important, though, is the question of whose
security and whose interests are at stake, or, more
specifically, of what the connection is between the
abstract public, or "national," interest and the spe-
cific and concrete interests of diverse national and
international constituencies. Also needed is an un-
derstanding of the linkages between domestic and
global concerns, above and beyond facile, danger-
ous, ethnocentric, and now outmoded ideological
ciches" (Nef, 1999: 12).

Ketika definisi human human security tetap merupakan pertanyaan yang terbuka, di situ ada konsensus di antara para pengembang gagasan bahwa akan ada perubahan orientasi dari keamanan yang semula statecentered menjadi people-centered. Reorientasi ini mengandung makna bahwa berkembangnya human security menuntut adanya peran yang lebih besar dari masyarakat baik individu maupun komunitas untuk lebih mampu menjamin kebutuhan akan keamanannya. Meskipun human security merupakan public goods yang mempersyaratkan pada negara untuk memikul tanggung jawabnya, namun harus ada ruang yang cukup bagi individu untuk melaksanankan kewajibannya secara komplementer bersama masyarakatnya dan terlibat dalam keseluruhan prosesnya. Sejalan dengan itu MacFarlane dan Khong mengingatkan bahwa: Human security tidak hanya sebatas tantangan
untuk melakukan perlindungan dan menjaminnya
akan tetapi mencakup pula penguatan akan parti-
sipasi mereka. Masyarakat bukanlah penikmat se-
cara pasif dari pelayanan keamanan atau sebagai
korban karena tiadanya jaminan keamanan, seba-
liknya mereka adalah subyek yang aktifyang harus
mampu berkontribusi secara langsung dalam
mengidentifikasi dan mengimplementasi solusi
terhadap masalah keamanan (MacFarlane dan
Khong, 2006).
UNDP pada tahun 1994 mencoba men-
definisikan human security melalui pende-
katan universal. Definisi tersebut bertolak
dari prinsip umum bahwa manusia secara
instinktif memahami apa makna security. 
Mereka pada umumnya memaknai security sebagai surety-kepastian, safety - keselamatan, protection - perlindungan dari ancaman permanen seperti kelaparan, penyakit, kejahatan dan tindakan represif dari pihak lain. Security juga dimaknai sebagai perlindungan dari berbagai kesulitan dan kejadian menyakitkan dalam menjalani kehidupannya sehari-hari apakah ketika mereka berada di rumah, di lingkungan pekerjaannya, di lingkungan masyarakatnya atau di lingkungan kehidupan pada umumnya. Selanjutnya Komisi human security PBB pada tahun 2003, menyatakan bahwa esensi human security berarti jaminan keselamatan (safety) untuk umat manusia baik dari ancaman kekerasan maupun ancaman tanpa kekerasan, dengan perkataan lain mereka bebas dari ancaman yang serius (pervasive threat) terhadap hak-hak asasi mereka. Hal inilah yang mendorong timbulnya reorientasi terhadap makna security yang semula lebih terfokus pada keamanan teritorial atau keamanan negara menjadi lebih terfokus pada keamanan insani/individu/manusia.

\section{Konteks Politik Wacana Negara Lemah}

Setelah Indonesia memasuki apa yang disepakati sebagai era reformasi, kekuasaan tidak lagi terkonsentrasi pada negara dengan pelaku utama militer, birokrasi, dan kaum konglomerat yang ketiganya menjadi agen kekuatan kapitalisme global, maka muncul kekuatan baru yaitu elite parpol. Kemudian elite baru inilah yang kemudian menjadi kelompok-kelompok penekan yang mengontrol kebijakan negara melalui jalur politik di parlemen. Fenomena ini mengindikasikan bahwa perkembangan politik Indonesia mengalami pergeseran karakter dari negara korporasi (corporatist state), menuju organic state.

Dalam negara seperti itu, konflik antarelite memanfaatkan momentum lemahnya negara, sehingga manajemen pemerintahan kian diwarnai oleh konfigurasi tarik-menarik kepentingan elite. Akibatnya berbagai persoalan mendasar, seperti kemiskinan, pengangguran massal, kesehatan masyarakat, dan distribusi pendapatan tidak tertangani dengan baik, sehingga kredibilitas pemerintah cenderung menurun di mata rakyat. Di samping itu, pengelolaan terhadap masalahmasalah prostitusi, perjudian, narkoba, dan pornografi tidak dapat ditangani secara tuntas oleh pemerintah.

Pada kurun waktu yang sama, berbagai bencana alam maupun akibat ulah manusia terus terjadi secara susul-menyusul yang diikuti oleh jatuhnya korban baik benda maupun manusia dalam jumlah yang besar. Mulai bencana gempa dan tsunami Aceh 2004, gempa bumi Yogyakarta 2006, semburan lumpur Lapindo Sidoarjo yang tidak kunjung mampat, gempa Padang, banjir bandang Wasior Papua, gempa dan tsunami Mentawai, dan terakhir erupsi Gunung Merapi yang disusul erupsi Gunung Bromo. Kemampuan negara dalam mengelola pemerintahan di bidang politik, ekonomi, dan sosial yang cenderung menurun berpengaruh terhadap citra diri negara di hadapan publik.

Di tengah kebebasan ekspresi berpendapat pasca Orde Baru, media massa semakin leluasa menjalankan peranannya, terutama dalam melakukan kontrol sosial. Tak heran ketika apresiasi dan kepercayaan publik terhadap lembaga-lembaga negara menurun, media massa menjadi tumpuah terakhir publik untuk mengambilperan sebagai alat kontrol dalam proses pengambilan keputusan. Kekuatan media untuk menggerakkan persepsi publik demikian besar. Hal itu tergambar dari setiap gempuran pemberitaan atas skandal atau isu yang melibatkan lembaga negara, sering disusul dengan hasil survei yang menunjukkan kemerosotan persepsi publik yang signifikan atas lembaga negara tersebut.

Perubahan konstelasi politik dari otoritarian ke demokrasi membawa implikasi pola hubungan antara media massa, nega$\mathrm{ra}$ / pemerintah, dan publik. Jika sebelumnya negara sangat dominan terhadap kekuatan di luarnya, termasuk media massa, maka pada era reformasi media berada dalam posisi sejajar dan bahkan dalam situasi ter- 
tentu lebih dominan. Di sinilah kemudian media televisi yang telah memiliki otonomi relatif terhadap negara, dengan leluasa mengkonstruksi negara yang ditampilkan dalam sosok besar tetapi rapuh, terutama pada saat menghadapi berbagai persoalan krusial yang berkaitan dengan fungsi melindungi warga dari gangguan keamanan.

Terakhir, strukturasi berkaitan dengan relasi ide antaragen masyarakat, proses sosial dan praktik sosial dalam analisis struktur. Strukturasi dapat digambarkan sebagai proses dimana struktur sosial saling ditegakkan oleh para agen sosial, dan bahkan masing-masing bagian dari struktur mampu bertindak melayani bagian yang lain. Hasil akhir dari strukturasi adalah serangkaian hubungan sosial dan proses kekuasaan diorganisasikan di antara kelas, gender, ras, dan gerakan sosial yang saling berhubungan. Gagasan tentang strukturasi ini pada mulanya dikembangkan oleh Anthony Giddens (Mosco, 1996: 212).

\section{Konteks Politik Wacana Tentara Nasional Kuat}

Sebagaimana diuraikan dalam analisis praktik wacana pada bab sebelumnya, ketika mengekspose pemberitaan seputar penyergapan terorisme, anarkisme massa, dan bencana Gunung Merapi, TV One dan Metro TV juga mewacanakan militer lebih sigap dalam melakukan evakuasi korban. Representasi dan konstruksi wacana oleh televisi seperti ini memang berhubungan dengan kondisi sosio-kultural dan politik yang berkembang di Indonesia. Dengan kata lain, latar belakang historis dan sosiologis yang berkembang di Indonesia selama ini memang memposisikan militer cukup dominan dalam percaturan politik nasional. Dominasi politik militer mempunyai akar historis yang panjang sejak era kerajaan yang memberikan peran penting bagi kalangan prajurit. Dominasi militer tersebut mengalami puncaknya ketika Indonesia berada dalam pemerintahan Orde Baru di bawah pimpinan Soeharto.

Meskipun pada era pasca-Soeharto dominasi militer mulai surut, secara umum per- sepsi bahwa militer layak menjadi pimpinan di berbagai bidang masih cukup signifikan. Beberapa Kepala Daerah, terutama di tingkat provinsi banyak yang dijabat oleh kalangan militer. Presiden Susilo Bambang Yudhoyono sendiri juga seorang jenderal dan menjadi satu-satunya presiden yang terpilih secara langsung oleh rakyat dengan perolehan suara signifikan, sekitar 62 persen. Bahkan, ia juga terpilih kembali pada periode kedua 2009/2014 dengan perolehan suara yang signifikan pula.

Peran militer hingga sekarang tetap penting sehingga di kalangan mereka sendiri tidak mau diabaikan untuk terlibat negara. Alasan utamanya adalah bahwa untuk menjaga keutuhan Negara Kesatuan Republik Indonesia (NKRI), maka terlalu riskan mengabaikan tentara. Lebih dari itu, memang harus diakui bahwa komitmen tentara terhadap NKRI dan dasar negara Pancasila adalah yang paling tinggi. Untuk itu, bagaimanapun tentara perlu mendapat tempat dalam manajemen pemerintahan, meskipun dalam konteks membangun demokrasi harus ditempatkan secara proporsional. Asumsinya bahwa jika tentara sudah bisa ditempatkan secara tepat dan proporsional dalam suatu bangunan sistem politik dan pemerintahan yang demokratis di masa depan, maka sejak awal tentara tidak akan merasa ditinggalkan dan diabaikan dalam menciptakan iklim kondusif bagi lancarnya proses transisi demokrasi.

Dalam konteks hubungan sipil-militer di negara-negara berkembang ada beberapa model teoretik yang berupaya memberikan penjelasan. Finer (1992: 190) misalnya, menawarkan tiga pola pergeseran peran militer dalam masa transisi, yaitu abdication, civilianization, dan quasi-civilianization. Pada pola abdication, militer turun tahta dan mengabdikan diri sepenuhnya bagi profesionalisme. Sementara pola civilianization, militer memberi kesempatan kepada sipil untuk menduduki posisi kepala pemerintahan dengan dukungan militer. Pola quasi-civilianization, militer memberi kesempatan pada institusi sipil untuk muncul kembali. Sedangkan Ulf Sundhaussen menawarkan model: 
(1) mempertahankan kekuasaan dan membatasi partisipasi masyarakat; (2) mempertahankan kekuasaan dan memperluas partisipasi masyarakat; (3) mengembalikan kekuasaan kepada sipil dan membatasi partisipasi; dan (4) mengembalikan kekuasaan kepada sipil dan memperluas partisipasi.

\section{Konteks Sosio-kultural Wacana Mistis}

Khususnya yang berkaitan dengan peristiwa erupsi Merapi, konstruksi televisi terhadap korban yang tercermin dalam pemberitaannya, sebenarnya yang hendak digelindingkan adalah wacana mitologis yang masih berkembang subur dalam masyarakat. Konstruksi seperti itu jelas berhubungan dengan kondisi sosio-kultural masyarakat lereng Gunung Merapi yang berkultur Jawa. Sebagaimana masyarakat Jawa, karakter utamanya adalah mempercayai adanya mitos dan mistik. Pengalaman mistik dan manunggaling kawula-Gusti merupakan kata kunci yang senantiasa ada dalam berbagai aspek kehidupan masyarakat yang masih berorientasi pada kebudayaan Jawa.

Praktik mistik Jawa dan formulasi jalan mistik didasarkan pada doktrin mengenai kesempurnaan manusia. Menurut doktrin ini, manusia merefleksikan sifat-sifat Tuhan. Siklus kehidupan dan pengalaman mistik dipahami sebagai sesuatu yang berasal dari Tuhan dan kembali kepada esensi ketuhanan. Namun demikian, konsep ketuhanan bagi paham Jawa bukan saja bersifat transenden, melainkan juga imanen. Oleh karena itu, seorang raja misalnya, menurut paham Jawa juga merefleksikan sifat Tuhan sehingga konsep manunggaling kawula-gusti juga berlaku pada hubungan antara rakyat dan raja atau pemimpinnya.

Dalam kebudayaan Jawa, secara praksis akan banyak dijumpai mitologisasi (memitoskan), sakralisasi (mengeramatkan), dan mistifikasi (memandang segala sesuatu sebagai misteri). Dalam buku primbon (orang Jawa menyebutnya sebagai kitab primbon) sangat sarat dengan ketiga unsur mistisisme Jawa tersebut. Dalam paham Jawa, ketiganya merupakan satu kesatuan dan tidak bisa dipisah-pisahkan. Mitologi Jawa misalnya, berkembang mitos Sunan Kalijaga, tokoh spiritual yang sangat dihormati secara mistik, dan mitos Nyai Roro Kidul, ratu laut Selatan. Tentang sakralisasi, orang Jawa percaya akan kemanjuran doa di makammakam keramat, gunung, sungai, sendhang, dan senthong. Juga ada bentuk sakralisasi dalam upacara-upacara mitoni dan tedhak siti. Sedangkan mistifikasi terlihat pada kepercayaan orang Jawa terhadap hubungan keberuntungan atau kerugian dengan arah mata angin, tanggal, dan naga dina.

Jika mengikuti proposisi Geertz (1974), bahwa kebudayaan bukan berada di antara pikiran-pikiran manusia, maka konsep utama Jawa, yaitu manunggaling kawula-gusti, mistisisme, harmoni atau keselarasan dan tentrem tersebut hingga kini ada dalam pikiran sebagian besar orang Jawa yang orientasi kebudayaan Jawanya masih kental. Atau jika Levy Strauss dalam bukunya Structural Anthropology (1968) menjelaskan bahwa struktur juga bersifat abstrak ada dalam pikiran manusia, maka konsep utama tersebut juga ada dalam struktur pikiran orang Jawa. Jika mengikuti pandangan strukturalis, maka tindakan individu orang Jawa dalam praktik kehidupan sehari-hari dipengaruhi oleh struktur kesadarannya tersebut. Dengan demikian, ekspresi atau tindakan budaya masyarakat Jawa sangat dipengaruhi oleh struktur kesadaran budayanya. Memang ada individu orang Jawa yang mampu menjadi aktor dan berupaya menyimpang atau bahkan mendekonstruksi konsep-konsep utama yang sudah terlembagakan tersebut. Akan tetapi orang-orang seperti ini, meskipun beretnis Jawa namun sudah tidak menjadi Jawa secara kebudayaan.

Dengan perspektif tersebut, kiranya akan semakin memahami secara substantif tentang agama orang Jawa. Sebab jika tidak, orang akan dengan mudah terjebak dalam pehaman yang keliru dan dengan mudah menyimpulkan agama orang Jawa adalah Islam, meskipun secara kuantitatif memang demikian. Clifford Geertz telah berhasil de- 
ngan baik ketika merekonstruksi praktik keberagamaan masyarakat Jawa, yang kemudian menemukan dua varian praktik keagamaan, yaitu abangan-priyayi dan santri. Geertz tanpa keraguan sedikit pun menyebut praktik keagamaan abangan-priyayi sebagai agama Jawi. Meskipun komunitas abangan dan priyayi pada umumnya mengaku memeluk Islam, tetapi dalam kehidupan sehari-hari tidak tampak mempraktikkan doktrin Islam. Bahkan secara substantif praktik-praktik spiritualnya sehari-hari, seringkali justru bertentangan dengan ajaran Islam, dan mereka melakukannya dengan kesadaran penuh dan mengaku memang berbeda dengan apa yang dianjurkan Islam.

Dalam konteks bencana Merapi, warga di sekitar lereng Gunung Merapi mempercayai bahwa gunung tersebut memiliki penjaga, yaitu apa yang dikenal dengan Kyai Sapu Jagad. Mitos tentang penjaga gunung sama dengan mitos penjaga Laut Selatan, yaitu Nyai Roro Kidul. Mitos ini hidup dan berkembang hingga sekarang. Bagi warga yang percaya, akan melakukan ritual khusus untuk sesaji guna mencari keselamatan. Sebagaimana warga lereng Merapi, secara sosiologis daerah ini merupakan masyarakat yang berkultur agraris, menggantungkan hidupnya dari hasil budidaya pertanian baik sawah maupun perkebunan rakyat.

Dari sisi politik, munculnya mitos-mitos tersebut sebenarnya merupakan produksi kalangan pengusa, dalam hal ini adalah keraton. Penciptaan mitologi adalah intrumen penting dalam tradisi kerajaan di Jawa demi meraih tujuan politik. Melalui mitologi, ia sekaligus menjadi alat untuk mengawasi rakyat agar terus tunduk pada kekuasaan keraton. Dengan menyebarkan ideologi penuh mistik, keraton terus membentuk kesadaran rakyat yang percaya bahwa semua kekuatan mistik tersebut memiliki hubungan dengan keraton. Pihak elite keraton dalam tradisi kekuasaan Jawa senantiasa membangun citra bahwa raja senantiasa memiliki otoritas untuk berkomunikasi dengan roh halus yang menjaga gunung dan laut Selatan. Citra bahwa hanya raja yang memiliki kemampuan berkomunikasi dengan roh halus sangat penting bagi upaya kemapanan kekuasaan. Dengan cara tersebut, rakyat takut dan patuh kepada raja, bukan dengan cara dipaksa, tetapi melalui kesadaran. Proses ini sebenarnya mirip dengan hegemonisasi sebagaimana yang diajukan oleh Gramsi. Dalam perspektif gramsian ideologisasi yang membidik kesadaran adalah instrumen penting untuk menundukkan obyek. Dalam konteks ini pihak keraton sesungguhnya telah melakukan hegemonisasi pada rakyat lereng Merapi demi tujuan kemapanan kekuasaan.

\section{SIMPULAN}

Dengan paparan diatas dapat kita katakan bahwa persoalan keamanan manusia dalam kaitannya dengan media dan negara demokrasi akan selalu menempatkan apakah negara dalam kondisi demokrasi, transisia ataukah otoriter. Jika negara transisional, maka masyarakat akan cenderung melakukan aktivitas yang menuju pada anarkhi dan terorisme, sementara jika negara demokratis, masyarakat akan cenderung berperilaku santun dan beradab. Sedangkan ketika negara otoriter, masyarakat akan cenderung keras dan benar-benar melakukan perlawanan sekalipun negara memposisikan dirinya sebagai negara kuat. Media sangat berperan dalam perspektif human security karena memberikan kontribusi yang jelas atas terjadinya konstruksi masyarakat dan negara, apakah negara kuat ataukah negara lemah. Media sangat berpengaruh dalam kajian keamanan manusia karena memiliki pelbagai kepentingan, ekonomi, politik, dan kebudayaan.

\section{DAFTAR PUSTAKA}

Berger, P L. dan Luckmann, T., 1966, The Social Construction of Reality. A Treatise in The Sociology of Knowledge. New York: Penguin Books.

Fairclogh, N., 1995, Media Discourse, London: Edward Arnold.

Hall, S., 1980, Encoding and Decoding, London: Methusen. 
Kazan Gunawan, Irwan Abdullah, dan Heru Nugroho -- Human Security dalam Negara Demokrasi:

1982, The Rediscovery of Ideology: The Return of the Repressed in Media Studies, dalam Michael Gurevitch, Tony Bennett, James Curran, dan Janet Woollacott (ed.), Culture, Society and the Media, London: Methusen.

McQuail's, D., 2005, Mass Communication Theory, Fifth Edition, London: Sage Publications.

Nef, I., 1999, Human Security and Mutual Vulnerability. Ottawa: International Develompent Research Centre.
Prabowo, J.S., 2009, Pokok-pokok Pemikiran tentang Perang Semesta. Jakarta: Pusat Pengkajian Strategi Nasional (PPSN).

Rosengren, K.E., 1981, Mass Media and Social Change: some current approaches, dalam E. Katz dan T. Szecsko (eds.), Mass Media and Social Change, hal. 247-63, Beverly Hill, CA: Sage.

Sardar Z., 2008, Membongkar Kuasa Media, Yogyakarta: Resist Book.

Thomas, C., 2000, Global Governance, Development and Human Security. London: Pluto Press. 